\title{
The Interaction Effects of Globalization and Institutions on International Capital Flows
}

\author{
Hannah G. Shell ${ }^{1}$ \& Liping Zheng ${ }^{2}$ \\ ${ }^{1}$ Federal Reserve Bank of St. Louis, St. Louis, Missouri (Note 1), USA \\ ${ }^{2}$ College of Business and Public Administration, Drake University, Des Moines, Iowa, USA \\ Correspondence: Liping Zheng, College of Business and Public Administration, Drake University, Des Moines, \\ Iowa 50311, USA. Tel: 1-515-271-4160. E-mail: liping.zheng@drake.edu
}

Received: January 28, 2015

Accepted: February 2, 2015

Online Published: March 25, 2015

doi:10.5539/ijef.v7n4p12

URL: http://dx.doi.org/10.5539/ijef.v7n4p12

\begin{abstract}
This paper examines how globalization and institutional quality affect international capital inflows. Using the KOF globalization index and its single dimensions (economic, social and political), we show that globalization and institutional quality not only individually have a significant positive impact on international capital flows, their interaction effects are also significant. In particular, the partial effect of globalization on capital inflows is decreasing with higher levels of institutional quality. As globalization expands and institutional quality improves, the return in capital flows increases at a decreasing rate. By decomposing globalization into its single dimensions, we find that social and economic globalization drive these results. Among components of social globalization, cultural proximity plays an important role in attracting capital inflows.
\end{abstract}

Keywords: capital flows, institutional quality, globalization

\section{Introduction}

Why are some countries richer and enjoying a higher level of standard of living? How can poor countries achieve long run economic growth? Growth theory predicts that capital accumulation and technological progress are the two major driving forces of economic growth. Capital flows not only directly increase capital accumulation in a host country, they also promote productivity through technology transfer. Capital flows therefore play a very important role in economic growth. A natural question to ask then is where does capital flow? A standard neoclassical production function with diminishing marginal productivity of capital suggests that capital should flow from capital-abundant rich countries to capital-scarce poor countries. However, Lucas (1990) shows that capital predominantly flows to the rich countries. The inconsistency between the theoretical prediction and the data is referred as the Lucas Paradox.

Many theoretical explanations to the Lucas Paradox have been proposed but relatively few empirical studies exist (Note 2). Alfaro, Kalemli-Ozcan and Volosovych (2008), in an empirical investigation of the paradox, found that institutional quality is an extremely important factor in determining capital flows. When controlling for institutional quality in a regression of gross domestic product (GDP) on capital flows, they found a negatively significant relationship between capital flows and GDP. This negative coefficient on GDP suggests that when institutional quality is taken into consideration, the Lucas Paradox no longer exists (Alfaro, Kalemli, \& Volosovych, 2008). Snyder (2012) qualified this finding by showing that different measures of institutional quality have different impacts on capital flows; moreover, the effect of institutional quality on capital flows is different in poor countries than in rich countries. Snyder's finding implies that institutional quality's impact on capital flows varies with the level of economic development. His finding also raised questions about whether institutional quality is truly a solution for the Lucas Paradox, as the positive and significant relationship between GDP and capital flows was maintained in several regression specifications (Synder, 2012). Okada (2013) further expanded on this literature by showing that institutional quality's relationship to capital also has an important interaction effect with financial openness. Specifically, Okada (2013) finds that the partial effect of financial openness on capital flows is increasing with higher levels of institutional quality. Okada's finding suggests that perhaps the solution to the Lucas Paradox lies somewhere in the relationship between a country's institutional quality and its openness to trade. 
In this study, we examine the role of globalization and institutional quality in attracting capital flows, treating globalization as a complex, multi-faceted term. Globalization is most commonly referred to strictly as an economic path, but it really is an ambiguous term with multiple dimensions (Rodrik, 2000; Vamvakidis, 2002; Aramberri, 2009). To study the several aspects of globalization, we employ a broad index developed by Dreher (2006), called the KOF index. The KOF index of globalization not only includes measurement on economic globalization, but also social and political dimensions of globalization (Note 3). By examining globalization more broadly, we show the interaction effects of globalization and institutions on international capital flows differ depending on the definition of globalization employed. Our results show that institutions and globalization (and its components) are individually positive and significant on capital flows, but their partial effect suggests decreasing capital flows with higher levels of institutional quality. By decomposing globalization into its single dimensions, we find that the social and economic aspects of globalization drive this relationship. Additionally, we find that controlling for the interaction effects between aspects social and economic globalization and institutional quality removes the significant and positive relationship between GDP and capital flows. This finding suggests that social and economic globalization and their interactions with institutional quality are two important factors to consider in solving the Lucas Paradox.

Globalization means many different things for different people (Note 4). In general, it means countries are becoming more integrated in terms of economic, social, informational, and technological exchanges, but it can also mean cultural and political convergence (Li \& Rueveny, 2003; Dreher, 2006). For example, McDonald's restaurants are now a global chain, with locations in over 100 countries (Note 5). Globalization has enabled the restaurant to go from an item in one nation's culture to an international symbol of cultural convergence. In terms of political convergence, Simmons and Elkins (2004) show that international policy diffusion can influence the decision making of domestic policy makers. Policy successes elsewhere, communicated through cultural linkages and information networks, can be a learning experience for domestic leaders (Axelrod, 1997). Leaders implement policies that are proven to be effective, and due to increased exchanges from globalization, policies across countries are less diverse.

In addition to having multiple dimensions, globalization does not occur in a vacuum. Like most macro-variables, globalization interacts with various aspects of a country's growth and values. For example, Chang and Lee (2010) find that social and political aspects of globalization specifically, along with globalization overall, have a long-run unidirectional impact on economic growth. Moreover, Granato, Inglehart, and Leblang (1996) show that cultural values can have an important impact on economic development. As globalization affects certain cultures, it has an indirect impact on development. Considering globalization as strictly economic is missing a large portion of the concept's identity, and also missing a portion of the concept's impact on economic outcomes. To examine the relationship between globalization and capital flows, therefore, we need to consider this multi-layer perspective of globalization.

This paper contributes to the literature in several ways. Primarily, we explore the hypothesis that globalization and institutional quality combined could be a solution to the Lucas Paradox. We start by estimating the interaction effect of broad indices representing globalization and institutional quality on capital flows. First, we test the independent relationship of capital flows to each of the broad indices, then we add the interaction term of globalization and institutional quality and find a significant relationship. Next, we explore the interaction effect in terms of the three sub-dimensions of globalization: economic, social, and political (Note 6). Upon finding that economic and social globalization have significant interaction effects with institutional quality, we examine the sub-components of each dimension in turn. The sub-component variables representing trade restrictions (component of economic globalization) and cultural proximity (component of social globalization) maintained the significant relationship. Finally, we unbundle the institution index and examine the interaction effects of the components of institutions with cultural proximity, finding that the social globalization component of cultural proximity has the strongest impact on capital flows when combined with strong regulatory and legal institutions (Note 7).

The paper continues as follows. Section 2 discusses empirical analysis, Section 3 describes the data. Section 4 presents and discusses regression results, and section 5 concludes.

\section{Empirical Strategy}

As mentioned above, this paper follows an empirical strategy similar to Alfaro, Kalemli-Ozcan, and Volosovych (2008). Instead of using panel data that varies across countries and time (like Synder, 2012; Okada, 2013), our dataset consists of country-level averages from 1970 to 2010 (Note 8). Using averaged variables over several years is a good way to study institutional quality and capital flows as they are both variables that are unlikely to 
change dramatically over time (Alfaro, Kalemli-Ozcan, \& Volosovych, 2008). Primarily, we are interested in understanding the interaction effect of institutional quality and globalization on capital flows, and particularly in the effects of globalization. We estimate the following equation (Note 9),

$$
\begin{aligned}
\log _{\text {Capflows }_{i}} & =\alpha+\beta_{0} \log G D P_{i}+\beta_{1} \text { Institutions }_{i}+\beta_{2} \text { Globalization }_{i} \\
& +\beta_{3} \text { Institutions }_{i} \times \text { Globalization }_{i}+\varepsilon_{i}
\end{aligned}
$$

where $i$ represents variation across countries, $\alpha$ is a constant term, and $\varepsilon$ is an independently and identically distributed error term. LogCapflows, is the log of average capital flows per capita per year, measured as the sum of foreign direct investment and portfolio equity flowing into a country in a particular year. $\log G D P$ is the log of real GDP per capita in the base year, 1970, and Institutions and Globalization are both indexes representing the level of institutional quality and social, political, and economic globalization. The regression is estimated using a standard OLS specification in STATA 13.

We start by estimating the interaction effect of globalization and institutional quality at the broadest level by using the summary indexes of globalization and institutional quality. After first testing the independent relationship of capital flows to these broad indices, we add the interaction term and find a significant relationship. Next, we explore the interaction effect in terms of the three sub-dimensions of globalization: economic, social, and political. Upon finding that economic and social globalization have significant interaction effects with institutional quality, we examine the sub-components of each dimension in turn. The component variables representing trade restrictions and cultural proximity maintained the significant relationship. Finally, we unbundle the institution index and examine the interaction effects of the components of institutional quality with cultural proximity.

Table 1. Summary statistics

\begin{tabular}{llllll}
\hline & Obs. & Mean & Std. Dev. & Min. & Max. \\
\hline $\log$ (Capital Flows per capita) & 111 & 3.89 & 2.21 & -2.46 & 8.67 \\
$\log$ (GDP per capita) in 1970 & 101 & 8.17 & 1.18 & 5.85 & 10.29 \\
Institutional Quality & 113 & 59.07 & 9.60 & 36.55 & 82.03 \\
Legal Property & 113 & 53.87 & 16.60 & 18.35 & 85.42 \\
Tariffs & 112 & 58.09 & 17.50 & 0.00 & 91.11 \\
Monetary Inst. & 113 & 66.76 & 15.99 & 13.98 & 96.08 \\
Regulations & 113 & 58.39 & 10.84 & 29.45 & 83.30 \\
Globalization & 113 & 50.42 & 16.00 & 21.87 & 84.46 \\
Economic Globalization & 113 & 50.40 & 17.28 & 15.98 & 92.26 \\
Trade Openness & 112 & 52.34 & 18.50 & 12.15 & 93.15 \\
Trade Restrictions & 112 & 49.06 & 21.84 & 8.80 & 91.37 \\
Social Globalization & 113 & 42.73 & 20.37 & 8.49 & 83.79 \\
Personal Contact & 111 & 48.64 & 21.51 & 8.42 & 88.52 \\
Info. Flows & 113 & 51.23 & 21.25 & 10.95 & 88.28 \\
Cultural Prox. & 113 & 28.03 & 23.97 & 1.00 & 86.75 \\
Political Globalization & 113 & 61.38 & 17.60 & 24.74 & 96.39 \\
Education & 108 & 2.03 & 1.13 & 0.20 & 5.15 \\
Agriculture Value Added (\% of GDP) & 109 & 16.45 & 13.60 & 0.37 & 54.33 \\
Roads Paved (\% of Total) & 112 & 48.82 & 32.19 & 0.82 & 100.00 \\
Inflation (GDP Deflator) & 111 & 6.92 & 11.34 & -3.71 & 102.33 \\
\hline
\end{tabular}

\section{Data Description}

The capital flows data come from the IMF's International Financial Statistics database (2013). Once downloaded, data are deflated to 1996 U.S. dollars using the U.S. Consumer Price Index available from the St. Louis Federal Reserve's data service, FRED. The real capital flows are then divided by each country's population, and averaged over the available time period. The average country in our sample received an average of $\$ 48.91$ dollars of capital inflows per capita per year from 1970 to 2010.

$\log G D P$ comes from the Penn Tables and is the only variable that is not averaged over the period studied. Instead, GDP is the value of a country's gross domestic product per capita in the base year (1970). We use the base year primarily to avoid the inevitable endogenous relationship between capital inflows and gross domestic product (Alfaro, Kalemli-Ozcan, \& Volosovych, 2008). In theory, GDP should show a negative relationship to 
capital flows; however, empirically it shows a positive relationship as established in Lucas (1990). If any of our estimated equations do show a negative relationship, we could argue that the additional variables have explained the Lucas paradox; however, we do not find a robust negative relationship (Alfaro, Kalemli-Ozcan, \& Volosovych, 2008; Synder, 2012). We do find a few circumstances where GDP is not significant, which could be an indication that the other factors included in the regression equation have more influence on capital than initial GDP.

Our two explanatory variables of interest are globalization and institutional quality. To represent globalization, we use the 2013 KOF Index of Globalization. The KOF Index is constructed using 23 variables that cover aspects of economic, political, and social globalization. The index is built by organizing 23 variables into the three sub-indices, then principal components analysis is used to combine the sub-indices into an overall globalization index (Dreher, 2006). The creators developed the index to reflect the process of developing extensive networks of people, information, capital, ideas, and physical goods across multiple continents (Dreher, 2006). We use all levels of the index in our analysis, starting with the broadest index of economic globalization, then examining the sub-indices of economic, political, and social dimensions of globalization, and finally looking at the component variables of social globalization.

The institutional quality data are chain-linked indices from the Economic Freedom of the World 2013 Annual Report. These indices are built using a standard process to standardize raw data from 0 to 10 scores. The raw data come from a variety of sources, including survey and quantitative data (for more information, see Free the world, Appendix). The annual report download includes sub-indices evaluating the size of government, legal system and property rights, sound money, freedom to trade internationally, and regulation. Our paper focuses on the summary index that includes all five sub-categories. We do include one set of regressions using individual sub-indices to address the precedent set in Snyder (2012) that says different forms of institutional quality might have different relationships with capital flows.

Other explanatory variables are included as control variables and are drawn from prior published datasets and the World Bank world development indicators. Education level is represented by the average years of secondary schooling in the population above 15 years of age, found in the Barro and Lee education database. Agriculture value added as a percent of GDP is drawn from the World Bank World Development Indicators (2013), along with paved roads as a percent of total roads (used as an infrastructure proxy), the population used to put GDP and capital flows in terms of per capita, and our measure of inflation (measured as the implicit growth of the GDP deflator).

Table 1 presents the summary statistics for the data used in our analysis. Log GDP per capita in the base year 1970 has a statistical average of 8.16, representing an average GDP per capita of about $\$ 3,500$. In 2013, the World Bank considered countries with per capita incomes below $\$ 4,085$ to be low or lower middle income (Note 10). By this measure, a little over half of the countries included in our analysis are considered low or lower middle income. The countries in our sample have a mean score of 59 points on the institutional quality index (out of 100 possible). Values closer to zero represent poor institutions, while values closer to 100 represent better institutions. Institutional data measuring legal property, tariffs, and legal regulations are overall below the institutional quality average for the countries in our sample, while monetary institutions are above average. The measure of institutional quality with the largest variance is tariffs, likely because some countries do not have tariffs at all, while others employ them extensively.

The statistical average of the overall index of globalization is 50.42. The economic globalization dimension of the index is distributed similarly to the overall index, although with a slightly larger variance. The social globalization dimension is distributed quite differently, with a lower overall average and higher variance. This large discrepancy likely comes from the component variables of social globalization-the information flows variable has a higher average, while cultural proximity is notably lower and has the lowest minimum value of all the globalization variables. Political globalization has the highest average value, meaning the countries in our sample are more globalized on a political dimension than on a social or economic one, confirming the necessity to research globalization as a multi-faceted term instead of strictly economic.

The additional control variables for our analysis are summarized in the bottom of Table 1. Education, or the average years of secondary schooling in the population older than 15 , has a statistical average of 2.03 years. On average, $16.45 \%$ of GDP for the countries in our sample comes from agricultural production, and the average country has $50 \%$ of its roads paved. Implicit inflation averages $6.92 \%$ per year.

\section{Results}

Table 2 presents the initial estimations of institutional quality's and globalization's effects on capital flows. The 
first column of Table 2 shows that our data, like many other studies, exhibits a positive relationship between capital flows and GDP per capita, or increasing returns to capital. According to the regression in column 1, a one percent increase in 1970 GDP per capita across countries leads to 1.54 percent higher capital inflows per capita without considering additional factors. As additional factors are included, the magnitude of positive returns declines but the relationship remains positive. In columns 2 and 3 of Table 2, institutions and globalization are each added separately to the regression in column 1. Both yield a positive and significant relationship to capital flows. In column four, the variables are included simultaneously and coefficients remain positive and significant.

In column 5 of Table 2 we estimate the interaction effect of institutional quality and globalization on capital flows. We find that the partial effect of overall globalization on capital flows is decreasing with the level of institutional quality. In other words, the negative coefficient shown on the interaction term in column 5 of Table 2 implies that globalized countries with strong institutions receive lower capital inflows than globalized countries with weaker institutions, holding other factors constant (Note 11). For example, the average country in our sample is predicted to receive about $\$ 167,000$ dollars of capital inflows per year. Holding other factors constant, increasing globalization one unit still increases the overall amount of capital flows to $\$ 186,000$, but the magnitude of the increase is lowered by the interaction effect (equal to $0.226+-0.002 *$ Institutional Quality). Also in column 5 we see that the coefficient on log GDP remains positive and significant. This finding implies that the interaction effect of globalization and institutional quality measured at their broadest levels is not enough to solve the Lucas Paradox.

The sign of the interaction effect between institutional quality and globalization is somewhat different than expected. Okada (2013) finds that the partial effect of financial globalization on capital flows is increasing with institutional quality. There are a few possible explanations for this difference. First, financial globalization is not necessarily the same as overall globalization. In fact, financial globalization as measured in Okada (2013), would be just one component of our measure of globalization. Moreover, many developing countries that rank low on measures of financial globalization could still rank high on broader measures that include factors like interpersonal contact. It is reasonable that a broader measure of globalization may yield a different relationship than a measure of just financial globalization. This finding could be evidence of capital seeking out corrupt or underdeveloped societies to increase profitability. Some leaders may be pressured to lower their labor standards or tax rates to draw in more capital - a key indication of weak institutions. If this is the case, between two countries with similar levels of globalization, the less-institutionalized country would bring in more capital.

Table 3. Institutions and components of globalization

\begin{tabular}{|c|c|c|c|c|}
\hline \multicolumn{5}{|c|}{ Independent Variable is $\log ($ Capital Flows per capita) } \\
\hline & (1) & (2) & (3) & (4) \\
\hline \multirow[t]{2}{*}{$\log ($ GDP per capita $)$} & 0.273 & $0.432 * *$ & 0.196 & $0.582 * * *$ \\
\hline & $(0.191)$ & $(0.166)$ & $(0.213)$ & $(0.211)$ \\
\hline \multirow[t]{2}{*}{ Institutions } & $0.174 * * *$ & $0.078 * *$ & $0.104^{* *}$ & $0.196 * * *$ \\
\hline & $(0.051)$ & $(0.039)$ & $(0.040)$ & $(0.065)$ \\
\hline \multirow[t]{2}{*}{ Institutions x Globalization } & $-0.002 * * *$ & & & \\
\hline & $(0.001)$ & & & \\
\hline \multirow[t]{2}{*}{ Globalization } & $0.227 * * *$ & & & \\
\hline & $(0.060)$ & & & \\
\hline \multirow[t]{2}{*}{ Institutions x Economic Globalization } & & $-0.001 *$ & & \\
\hline & & $(0.001)$ & & \\
\hline \multirow[t]{2}{*}{ Economic Globalization } & & $0.153 * * *$ & & \\
\hline & & $(0.043)$ & & \\
\hline \multirow[t]{2}{*}{ Institutions x Social Globalization } & & & $-0.001^{*}$ & \\
\hline & & & $(0.001)$ & \\
\hline \multirow[t]{2}{*}{ Social Globalization } & & & $0.141^{* * *}$ & \\
\hline & & & $(0.052)$ & \\
\hline \multirow[t]{2}{*}{ Institutions x Political Globalization } & & & & $-0.002 *$ \\
\hline & & & & $(0.001)$ \\
\hline \multirow[t]{2}{*}{ Political Globalization } & & & & $0.101 *$ \\
\hline & & & & $(0.056)$ \\
\hline Education & -0.135 & 0.055 & -0.133 & 0.051 \\
\hline
\end{tabular}




\begin{tabular}{lcccc}
\hline \multirow{3}{*}{ Agriculture (\% of GDP) } & $(0.172)$ & $(0.152)$ & $(0.184)$ & $(0.200)$ \\
& -0.013 & -0.009 & $-0.031^{*}$ & $-0.036^{*}$ \\
Roads Paved (\% of total) & $(0.017)$ & $(0.015)$ & $(0.017)$ & $(0.018)$ \\
& -0.004 & -0.002 & -0.004 & 0.0004 \\
Inflation & $(0.004)$ & $(0.004)$ & $(0.005)$ & $(0.005)$ \\
& $-0.033^{*}$ & $-0.050^{* * *}$ & -0.031 & $-0.039^{*}$ \\
Constant & $(0.018)$ & $(0.016)$ & $(0.019)$ & $(0.020)$ \\
& $-11.992^{* * *}$ & $-7.686^{* * *}$ & $-5.284^{*}$ & $-12.137^{* *}$ \\
$\mathrm{R}^{2}$ & $(3.563)$ & $(2.739)$ & $(2.881)$ & $(4.609)$ \\
Observations & 0.82 & 0.85 & 0.79 & 0.76 \\
\hline
\end{tabular}

Note. $* \mathrm{p}<0.1 ; * * \mathrm{p}<0.05 ; * * * \mathrm{p}<0.01$. Standard Errors in Parentheses.

Table 4. Institutions and components of economic and social globalization

\begin{tabular}{|c|c|c|c|c|}
\hline \multicolumn{5}{|c|}{ Independent Variable is $\log ($ Capital Flows per capita) } \\
\hline & (1) & (2) & (4) & (5) \\
\hline \multirow[t]{2}{*}{$\log$ (GDP per capita) } & $0.596^{* * *}$ & $0.356^{*}$ & 0.305 & $0.484 * *$ \\
\hline & $(0.182)$ & $(0.203)$ & $(0.218)$ & $(0.206)$ \\
\hline \multirow[t]{2}{*}{ Institutions } & 0.060 & $0.124 * * *$ & 0.078 & $0.121^{* * *}$ \\
\hline & $(0.039)$ & $(0.043)$ & $(0.050)$ & $(0.029)$ \\
\hline \multirow[t]{2}{*}{ Institutions x Trade Openness } & -0.0003 & & & \\
\hline & $(0.001)$ & & & \\
\hline \multirow[t]{2}{*}{ Trade Openness } & 0.057 & & & \\
\hline & $(0.039)$ & & & \\
\hline \multirow[t]{2}{*}{ Institutions x Trade Restrictions } & & $-0.001 * *$ & & \\
\hline & & $(0.001)$ & & \\
\hline \multirow[t]{2}{*}{ Trade Restrictions } & & $0.134 * * *$ & & \\
\hline & & $(0.048)$ & & \\
\hline \multirow[t]{2}{*}{ Institutions $\mathrm{x}$ Info. Flows } & & & -0.0001 & \\
\hline & & & $(0.001)$ & \\
\hline \multirow{2}{*}{ Info. Flows } & & & 0.046 & \\
\hline & & & $(0.050)$ & \\
\hline \multirow[t]{2}{*}{ Institutions x Cultural Prox. } & & & & $-0.002 * *$ \\
\hline & & & & $(0.001)$ \\
\hline \multirow[t]{2}{*}{ Cultural Prox. } & & & & $0.120 * * *$ \\
\hline & & & & $(0.045)$ \\
\hline \multirow[t]{2}{*}{ Education } & 0.137 & -0.066 & -0.099 & 0.009 \\
\hline & $(0.169)$ & $(0.181)$ & $(0.191)$ & $(0.197)$ \\
\hline \multirow[t]{2}{*}{ Agriculture ( $\%$ of GDP) } & -0.019 & $-0.031^{*}$ & $-0.033^{*}$ & $-0.037 * *$ \\
\hline & $(0.016)$ & $(0.017)$ & $(0.018)$ & $(0.017)$ \\
\hline \multirow[t]{2}{*}{ Roads Paved ( $\%$ of total) } & 0.003 & -0.003 & -0.003 & 0.001 \\
\hline & $(0.004)$ & $(0.005)$ & $(0.005)$ & $(0.005)$ \\
\hline \multirow[t]{2}{*}{ Inflation } & $-0.048 * * *$ & $-0.045^{* *}$ & $-0.033^{*}$ & $-0.033^{*}$ \\
\hline & $(0.018)$ & $(0.019)$ & $(0.020)$ & $(0.020)$ \\
\hline \multirow[t]{2}{*}{ Constant } & $-6.399 * *$ & $-7.426^{* *}$ & -4.186 & $-6.886 * * *$ \\
\hline & $(2.759)$ & $(3.055)$ & $(3.461)$ & $(2.359)$ \\
\hline $\mathrm{R}^{2}$ & 0.82 & 0.8 & 0.78 & 0.77 \\
\hline Observations & 90 & 89 & 90 & 90 \\
\hline
\end{tabular}

Note. $* \mathrm{p}<0.1 ; * * \mathrm{p}<0.05 ; * * * \mathrm{p}<0.01$. Standard Errors in Parentheses.

To test the robustness of this finding, the first column of Table 3 adds in education, agriculture as a percent of GDP, paved roads, and inflation as control variables. The results for the interaction effect of institutional quality and globalization are unchanged; however, with the addition of these variables log GDP is no longer significant. This regression suggests that the interaction effect of institutions and globalization, along with the selected control 
variables, are important factors to consider in solving the Lucas paradox.

Table 5. Cultural proximity and components of institutional quality

\begin{tabular}{|c|c|c|c|c|}
\hline \multicolumn{5}{|c|}{ Independent Variable is $\log ($ Capital Flows per capita) } \\
\hline & $(1)$ & (2) & (3) & (4) \\
\hline \multirow[t]{2}{*}{$\log$ (GDP per capita) } & $0.500 * *$ & $0.597 * * *$ & $0.487 * *$ & $0.498 * *$ \\
\hline & $(0.198)$ & $(0.223)$ & $(0.211)$ & $(0.211)$ \\
\hline \multirow[t]{2}{*}{ Cult. Proximity } & $0.079 * * *$ & 0.07 & $0.059^{*}$ & $0.114 * * *$ \\
\hline & $(0.030)$ & $(0.046)$ & $(0.031)$ & $(0.039)$ \\
\hline \multirow[t]{2}{*}{ Cult. Proximity x Legal Property } & $-0.001 * *$ & & & \\
\hline & $(0.000)$ & & & \\
\hline \multirow[t]{2}{*}{ Legal Property } & $0.079 * * *$ & & & \\
\hline & $(0.015)$ & & & \\
\hline \multirow[t]{2}{*}{ Cult. Proximity x Monetary Inst. } & & -0.001 & & \\
\hline & & $(0.001)$ & & \\
\hline \multirow[t]{2}{*}{ Monetary Inst. } & & 0.012 & & \\
\hline & & $(0.019)$ & & \\
\hline \multirow[t]{2}{*}{ Cult. Proximity x Tariffs } & & & -0.001 & \\
\hline & & & $(0.000)$ & \\
\hline \multirow[t]{2}{*}{ Tariffs } & & & $0.056^{* * *}$ & \\
\hline & & & $(0.014)$ & \\
\hline \multirow[t]{2}{*}{ Cult. Proximity x Regulation } & & & & $-0.001 * *$ \\
\hline & & & & $(0.001)$ \\
\hline \multirow[t]{2}{*}{ Regulation } & & & & $0.083 * * *$ \\
\hline & & & & $(0.023)$ \\
\hline \multirow[t]{2}{*}{ Education } & -0.011 & 0.091 & 0.017 & 0.008 \\
\hline & $(0.188)$ & $(0.224)$ & $(0.196)$ & $(0.199)$ \\
\hline \multirow[t]{2}{*}{ Agriculture ( $\%$ of GDP) } & $-0.037 * *$ & $-0.044 * *$ & $-0.036^{* *}$ & $-0.044 * *$ \\
\hline & $(0.017)$ & $(0.019)$ & $(0.018)$ & $(0.017)$ \\
\hline \multirow[t]{2}{*}{ Roads Paved (\% of total) } & -0.003 & 0.002 & 0.002 & 0.003 \\
\hline & $(0.005)$ & $(0.005)$ & $(0.005)$ & $(0.005)$ \\
\hline \multirow[t]{2}{*}{ Inflation } & $-0.040 * *$ & $-0.053^{* *}$ & $-0.042 * *$ & $-0.043 * *$ \\
\hline & $(0.018)$ & $(0.021)$ & $(0.020)$ & $(0.020)$ \\
\hline \multirow[t]{2}{*}{ Constant } & $-3.806^{*}$ & -1.735 & -2.997 & $-4.888 * *$ \\
\hline & $(1.972)$ & $(2.398)$ & (1.991) & $(2.179)$ \\
\hline $\mathrm{R}^{2}$ & 0.80 & 0.73 & 0.77 & 0.76 \\
\hline Observations & 90 & 90 & 89 & 90 \\
\hline
\end{tabular}

Note. $* \mathrm{p}<0.1 ; * * \mathrm{p}<0.05 ; * * * \mathrm{p}<0.01$. Standard Errors in Parentheses.

Because the index of globalization is an extremely broad measure with several sub-components, the rest of Table 3 and Table 4 regress the components of the globalization index on capital flows. Each regression includes log GDP per capita, a component of globalization, the summary index of institutional quality, and the interaction term between globalization and institutional quality. The globalization index is first broken into economic, social, and political globalization sub-groups, then broken down into the component metrics that make up each of the subgroups. The control variables added to the first regression in column 1 of Table 3 are included in every subsequent estimation.

The economic, social, and political subgroups are presented in columns 2-4 of Table 3. Similar to the results found for the broad index, the partial effects of economic, social, and political globalization on capital flows are all found to be decreasing with institutional quality. The relationships are all remarkably similar, institutions and globalization are individually positive and significant, and their partial effect suggests decreasing capital flows with higher levels of institutional quality. The similarity further confirms the results found in Table 2 . The results also confirm the need to study globalization as more than a strictly economic variable. Columns 3 and 4 of Table 3 show that even when economic aspects of globalization are not considered, it is still an important factor in determining capital flows. Out of all three sub-components, the regression including social globalization is the 
only one without a significant coefficient on log GDP, suggesting the social component of globalization could be the most important factor to resolving the paradox.

In an attempt to isolate the factor responsible for the results in Table 3, Table 4 runs the same regressions with the sub-components of economic and social globalization. Columns 1 and 2 present economic globalization's components, while columns 3 and 4 present those for social globalization. Although the coefficient on log GDP remains positive and significant on most regressions (Note 12), trade restrictions and cultural proximity have the same significant interaction effects with institutions as found in Tables 2 and 3 (Note 13). These findings suggest that becoming more culturally accessible to westernized countries and decreasing trade restrictions are both key actions that can bring capital into a country. Additionally, the significance of these sub-factors of the globalization index confirms that the results found in Tables 2 and 3 are not based on a spurious interaction between the broad measures of institutions and globalization. The results for trade restrictions are, again, largely expected and pre-established in Okada (2013); however, the results for cultural proximity are an addition to the literature.

Table 5 further analyzes these results by unbundling the institutional quality variable. Several prior studies have proposed that institutional quality indexes could be too broad to capture the effect of institutions on the Lucas Paradox. Both Okada (2013) and Snyder (2012) investigate the effects of sub-components of institutional quality on capital flows. We investigate four sub-components of the broad measure of institutional quality: sanctity of legal property, quality of monetary institutions, degree to which tariffs are used, and regulation of established policies. The only significant interaction effects of cultural proximity and the unbundled institutions are with legal property (column 1) and regulation (column 4), suggesting the enforcement and regulation of institutions along with the sanctity of property are both important factor for international capital flows.

\section{Conclusions}

Examining the relationship between three dimensions of globalization and capital flows reveals a positive relationship between globalization (and its components) and capital flows. In addition to the main result, our analysis generates several additional findings worthy of further investigation. First, when looking at the interaction term between globalization and institutional quality, the partial effect suggests decreasing capital flows with higher levels of institutional quality. An extension of this study could divide the sample into developed and developing countries and see if the results would remain the same. Second, among the components of economic and social globalization, trade restrictions and cultural proximity play a very important role. These findings suggest that becoming more culturally accessible to westernized countries, and decreasing trade restrictions are both key actions that can bring capital into a country. Finally, social and economic globalization interact with institutional quality in a way that could provide a solution to the Lucas Paradox, although more evidence is needed to conclude the existence of a robust relationship.

\section{Acknowledgments}

The authors thank College of Business and Public Administration (CBPA) at Drake University for financial support. The authors also thank the anonymous reviewers for their helpful comments.

\section{References}

Alfaro, L., Kalemli-Ozcan, S., \& Volosovych, V. (2008). Why doesn’t capital flow from rich to poor countries? An empirical investigation. The Review of Economics and Statistics, 90(2), 347-368. http://dx.doi.org/10.1162/rest.90.2.347

Aramberri, J. (2009). The future of tourism and globalization: Some critical remarks. Futures, 41(6), 367-376. http://dx.doi.org/10.1016/j.futures.2008.11.015

Axelrod, R. (1997). The dissemination of culture a model with local convergence and global polarization. Journal of Conflict Resolution, 41(2), 203-226. http://dx.doi.org/10.1177/0022002797041002001

Chang, C. P., \& Lee, C. C. (2010). Globalization and economic growth: A political economy analysis for OECD countries. Global Economic Review, 39(2), 151-173. http://dx.doi.org/10.1080/1226508X.2010.483835

Dreher, A. (2006). Does globalization affect growth? Evidence from a new index of globalization. Applied Economics, 38(10), 1091-1110. http://dx.doi.org/10.1080/00036840500392078

Gertler, M., \& Rogoff, K. (1990). North-South lending and endogenous domestic capital market inefficiencies. Journal of Monetary Economics, 26(2), 245-266. http://dx.doi.org/10.1016/0304-3932(90)90022-V

Gomme, P. (1993). Money and growth revisited: Measuring the costs of inflation in an endogenous growth model. Journal of Monetary Economics, 32(1), 51-77. http://dx.doi.org/10.1016/0304-3932(93)90035-E 
Gordon, R. H., \& Bovenberg, A. L. (1996). Why is capital so immobile internationally? Possible explanations and implications for capital income taxation. The American Economic Review, 1057-1075.

Granato, J., Inglehart, R., \& Leblang, D. (1996). The effect of cultural values on economic development: Theory, hypotheses, and some empirical tests. American Journal of Political Science, 607-631. http://dx.doi.org/10.2307/2111786

Gwartney, J., Lawson, R., \& Hall, J. (2013). Economic Freedom Dataset, published in Economic Freedom of the World: 2013 Annual Report. Fraser Institute. Retrieved from http://www.freetheworld.com/datasets_efw.html

Heston, A., Summers, R., \& Anan, B. (2012). Penn World Table Version 7.1, Center for International Comparisons of Production, Income and Prices. University of Pennsylvania, Nov 2012.

International Monetary Fund. (2013). International Financial Statistics. Washington, DC: The International Monetary Fund.

Kacowicz, A. M. (1999). Regionalization, globalization, and nationalism: Convergent, divergent, or overlapping? Alternatives, 527-555. Retrieved from http://www.jstor.org/stable/40644977

King, R., \& Rebelo, S. (1993). Transitional dynamics and economic growth in the neoclassical model. American Economic Review, 83(4), 908-931.

Kuncic, A. (2014). Institutional Quality Dataset. Journal of Institutional Economics.

Li, Q., \& Reuveny, R. (2003). Economic globalization and democracy: An empirical analysis. British Journal of Political Science, 33(1), 29-54. http://dx.doi.org/10.1017/S0007123403000024

Lucas, R. E. (1990). Why doesn't capital flow from rich to poor countries? The American Economic Review, 92-96.

Okada, K. (2013). The interaction effects of financial openness and institutions on international capital flows. Journal of Macroeconomics, 35, 131-143. http://dx.doi.org/10.1016/j.jmacro.2012.11.003

Razin, A., \& Yuen, C. W. (1994). Convergence in growth rates: The role of capital mobility and international taxation (No. w4214). National Bureau of Economic Research.

Rodrik, D. (2000). How far will international economic integration go? Journal of Economic Perspectives, 14, 177-186. http://dx.doi.org/10.1257/jep.14.1.177

Simmons, B. A., \& Elkins, Z. (2004). The globalization of liberalization: Policy diffusion in the international political economy. American Political Science Review, 98(1), 171-189. http://dx.doi.org/10.1017/S0003055404001078

Snyder, T. J. (2012). Increasing Returns, Institutions, and Capital Flows. Eastern Economic Journal, 39, $285-308$. http://dx.doi.org/10.1057/eej.2012.8

Tornell, A., \& Velasco, A. (1992). The tragedy of the commons and economic growth: Why does capital flow from poor to rich countries? Journal of Political Economy, 1208-1231. http://dx.doi.org/10.1086/261858

Vamvakidis, A. (2002). How robust is the growth-openness connection? Historical evidence. Journal of Economic Growth, 7(1), 57-80. http://dx.doi.org/10.1023/A:1013418610712

\section{Notes}

Note 1. The views expressed in this article are those of the individual authors and do not necessarily reflect the views of the Federal Reserve Bank of St. Louis, the Board of Governors, or the Federal Reserve System.

Note 2. For explanations based on differences in fundamentals, see King and Rebelo (1993), Razin and Yuen (1994), Gomme (1993), and Tornell and Velasco (1992); for international market imperfections, see Gertler and Rogoff (1990) and Gordon and Bovenberg (1996).

Note 3. The acronym KOF from Konjunkfurforschungsstelle, the institute where the index is published and can be downloaded: http://kof.ethz.ch/

Note 4. See Kacowicz (1999).

Note 5. See "Getting to Know Us" Webpage http://www.aboutmcdonalds.com/mcd/our_company.html 
Note 6 . When we break down the globalization index into its component variables, we drop the broader level of the index and employ its sub-components in our regression model instead. For example, we start with the broadest level of globalization, then instead of including the broad index, we include the sub-indexes of economic, political, and social globalization.

Note 7. For a study of the interaction effects between economic globalization and the sub-components of institutional quality, see Okada (2013).

Note 8. Alfaro, Kalemli-Ozcan, and Volosovych (2008) give several reasons why panel data may be inappropriate for studying institutional quality and capital flows. Primarily, institutional quality and capital flows are thought to change slowly over time, and using averages in place of panel data helps reduce concerns of endogeneity.

Note 9. We use log averages of capital flows per capita and GDP because 1) the level of average capital flows per capita is very skewed and taking logs makes it more normal; 2) Only two countries have negative average capital flows over the years (Libya and Mauritania) and we drop them from the analysis.

See http://data.worldbank.org/news/new-country-classifications for more information on country income classifications.

Note 10. See http://data.worldbank.org/news/new-country-classifications for more information on country income classifications.

Note 11. To verify the robustness of this finding, the analysis in Table 2 was repeated with an alternative measure of institutional quality. The results were unchanged so they are not presented here, but are available from the authors upon request.

Note 12. Although the coefficient on GDP is not significant in column 3 of table 4, we don't focus on this regression because the interaction effect of information flows and institutional quality is not significant.

Note 13. Because trade restrictions is used in an index to represent economic globalization, it is calculated as an inverse variable to be positively correlated with globalization. In other words, higher levels represent lower trade restrictions. Cultural proximity includes factors like the number of McDonald's Restaurants per capita, and the Number of Ikea per capita. For more information, see http://globalization.kof.ethz.ch./media/filer_public/2014/04/15/definitions_2014.pdf.

Appendix A1. Countries Included (113)

\begin{tabular}{llll}
\hline Albania & Ecuador & Kuwait & Romania \\
Argentina & Egypt, Arab Rep. & Sri Lanka & Russian Federation \\
Australia & Spain & Lithuania & Rwanda \\
Austria & Estonia & Latvia & Senegal \\
Burundi & Finland & Morocco & Singapore \\
Belgium & Fiji & Madagascar & Sierra Leone \\
Benin & France & Mexico & El Salvador \\
Bangladesh & Gabon & Mali & Slovak Republic \\
Bulgaria & United Kingdom & Malta & Slovenia \\
Bahrain & Ghana & Myanmar & Sweden \\
Bahamas, The & Greece & Mauritius & Syrian Arab Republic \\
Belize & Guatemala & Malawi & Chad \\
Bolivia & Guyana & Malaysia & Togo \\
Brazil & Honduras & Niger & Thailand \\
Barbados & Croatia & Nigeria & Trinidad and Tobago \\
Botswana & Haiti & Nicaragua & Tunisia \\
Canada & Hungary & Netherlands & Turkey \\
Switzerland & Indonesia & Norway & Tanzania \\
Chile & India & Nepal & Uganda \\
China & Ireland & New Zealand & Ukraine \\
Cote d'Ivoire & Iran, Islamic Rep. & Oman & Uruguay \\
Cameroon & Israel & United States \\
Congo, Rep. & & Venezuela, RB \\
\hline
\end{tabular}




\begin{tabular}{llll}
\hline Colombia & Italy & Peru & South Africa \\
Costa Rica & Jamaica & Philippines & Zambia \\
Cyprus & Jordan & Papua New Guinea & Zimbabwe \\
Germany & Japan & Poland & \\
Denmark & Kenya & Portugal & \\
Algeria & Korea, Rep. & Paraguay & \\
\hline
\end{tabular}

\section{Copyrights}

Copyright for this article is retained by the author(s), with first publication rights granted to the journal.

This is an open-access article distributed under the terms and conditions of the Creative Commons Attribution license (http://creativecommons.org/licenses/by/3.0/). 